\title{
Synthesis and Antimicrobial Activity of Some Isoxazole Derivatives of Thiophene
}

\author{
KAMALA CHAND GAUTAM ${ }^{\mathrm{a}^{*}}$ and DHARMCHAND PRASAD SINGH ${ }^{\mathrm{b}}$ \\ ${ }^{a}$ College of Pharmacy, IFTM, Moradabad (U.P.), India \\ ${ }^{\mathrm{b}}$ College of Pharmacy, SR group of Institutions, Jhansi (U.P.), India \\ getkcgautamhere@gmail.com
}

Received 10 December 2012 / Accepted 12 January 2013

\begin{abstract}
A series of new chalcones were synthesized by the reaction of 2-acetyl thiophene and substituted bezaldehydes. Then the chalcones were made to undergo cyclization reaction with hydroxylamine hydrochloride in ethanol to afford the synthesis of isoxazole derivatives of thiophene. The synthesized compounds were purified and their structures were elucidated with the help of IR and ${ }^{1} \mathrm{H}$ NMR spectroscopy. The compounds were screened for antimicrobial activity by disc diffusion method. The result suggested that the four compounds were moderately to highly active.
\end{abstract}

Keywords: 2-Acetyl thiophene, Chalcones, Hydroxylamine hydrochloride, Isoxazoles, Antimicrobial activity

\section{Introduction}

Isoxazoles have been reported to possess diverse biological activities like antiinflammatory $^{1}$, antibacterial ${ }^{2}$, antifungal ${ }^{3}$, antibiotic ${ }^{4}$, anticonvulsant ${ }^{5}$, antitubercular ${ }^{6}$, anxeolytic ${ }^{7}$ properties. Ngaini et $a l^{8}{ }^{8}$ reported the various activities of chalcones, exhibiting anti-inflammatory, antimicrobial, anti malarial, anticancer, antioxidant, antihyperglycemic, antiangiogenic and antiplatelet activities. A little regarding the introduction of thiophene moiety to isoxazole ring has been reported, therefore, it was thought worthwhile to synthesis some new isoxazole derivatives attached to thiophene heterocyclic ring and evaluate them for their antimicrobial activity.

\section{Experimental}

The chemical synthesis was initiated by synthesizing different chalcones (Scheme 1) by the literature method ${ }^{9}$. A summary of synthesized chalcones are described in the Table 1. Then the isoxazole derivatives were prepared by adopting a general method in which the synthesized chalcones were treated with hydroxylamine hydrochloride in ethanol to afford the synthesis of isoxazole derivatives of thiophene (Scheme 2). 


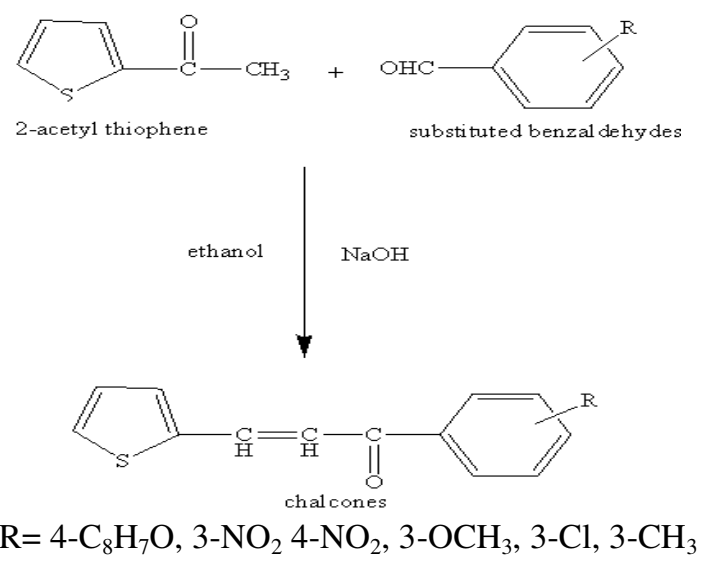

Scheme 1. Synthesis of chalcones

Table 1. General structure of synthesized chalcones

\begin{tabular}{cccccccc}
\hline $\begin{array}{c}\text { S. } \\
\text { No. }\end{array}$ & $\begin{array}{c}\text { Intermediate } \\
\text { Compound } \\
\text { Code }\end{array}$ & $\mathrm{R}$ & $\begin{array}{c}\text { Molecular } \\
\text { Formula }\end{array}$ & $\begin{array}{c}\mathrm{M} . \mathrm{P} ., \\
{ }^{\circ} \mathrm{C}\end{array}$ & $\begin{array}{c}\text { Yield, } \\
\%\end{array}$ & $\begin{array}{c}\mathrm{R}_{\mathrm{f}} \\
\text { Value }\end{array}$ & $\begin{array}{c}\text { Solvent } \\
\text { system }\end{array}$ \\
\hline 1. & $\mathrm{P}-1$ & $4-\mathrm{C}_{8} \mathrm{H}_{7} \mathrm{O}$ & $\mathrm{C}_{20} \mathrm{H}_{16} \mathrm{O}_{2} \mathrm{~S}$ & $59-60$ & $60 \%$ & 0.73 & $\begin{array}{c}n \text {-hexane:ethyl } \\
\text { acetate, } 2: 1 \\
n \text {-hexane:ethyl } \\
\text { acetate, } 2: 1\end{array}$ \\
2. & $\mathrm{P}-2$ & $4-\mathrm{NO}_{2}$ & $\mathrm{C}_{13} \mathrm{H}_{9} \mathrm{NO}_{3} \mathrm{~S}$ & $134-135$ & $55 \%$ & 0.60 & $\begin{array}{c}n \text {-hexane:ethyl } \\
\text { acetate, } 2: 1\end{array}$ \\
3. & $\mathrm{P}-3$ & $3-\mathrm{OCH}_{3}$ & $\mathrm{C}_{14} \mathrm{H}_{12} \mathrm{O}_{2} \mathrm{~S}$ & $61-62$ & $70 \%$ & 0.79 & $\begin{array}{c}n \text {-hexane:ethyl } \\
\text { acetate, } 2: 1\end{array}$ \\
4. & $\mathrm{P}-4$ & $3-\mathrm{NO}_{2}$ & $\mathrm{C}_{13} \mathrm{H}_{9} \mathrm{O}_{3} \mathrm{~S}$ & $129-130$ & $60 \%$ & 0.65 & $\begin{array}{c}n \text {-hexane:ethyl } \\
\text { acetate, } 2: 1\end{array}$ \\
5. & $\mathrm{P}-5$ & $3-\mathrm{Cl}$ & $\mathrm{C}_{13} \mathrm{H}_{9} \mathrm{ClOS}$ & $79-80$ & $65 \%$ & 0.84 & $\begin{array}{c}n \text {-hexane:ethyl } \\
\text { acetate, } 2: 1\end{array}$ \\
\hline 6 & $\mathrm{P}-6$ & $3-\mathrm{CH}_{3}$ & $\mathrm{C}_{14} \mathrm{H}_{12} \mathrm{OS}$ & $69-70$ & $55 \%$ & 0.88 & \\
\hline
\end{tabular}

To a solution of different $\left(\mathrm{P}_{1}-\mathrm{P}_{6}\right)$ chalcones $(0.01$ mole $)$ in ethanol and anhydrous sodium acetate $(0.81 \mathrm{~g}, 0.01$ mole $)$ dissolved in minimum amount of acetic acid, solution of hydroxylamine hydrochloride was added. The reaction mixture was refluxed on oil bath for hours. The completion of reaction was monitored by TLC. After the completion of reaction, the solution was cooled to get the products, which were purified by recrystallization from ethanol. The synthesized thiophene derivatives are described in Table 2.

Table 2. Physical parameters of synthesized compounds

\begin{tabular}{cccccccc}
\hline $\begin{array}{c}\text { S. } \\
\text { No. }\end{array}$ & $\begin{array}{c}\text { Compd } \\
\text { Code }\end{array}$ & $\mathrm{R}$ & $\begin{array}{c}\text { Molecular } \\
\text { Formula }\end{array}$ & $\begin{array}{c}\text { M.P., }{ }^{\circ} \mathrm{C} \\
\text { range }\end{array}$ & $\begin{array}{c}\text { Yield, } \\
\%\end{array}$ & $\begin{array}{c}\mathrm{R}_{\mathrm{f}} \\
\text { value }\end{array}$ & $\begin{array}{c}\text { Reaction } \\
\text { time, h }\end{array}$ \\
\hline 1. & KCG-1 & $4-\mathrm{C}_{8} \mathrm{H}_{7} \mathrm{O}$ & $\mathrm{C}_{20} \mathrm{H}_{17} \mathrm{NO}_{2} \mathrm{~S}$ & $71-72$ & $60 \%$ & 0.58 & 15 \\
2. & KCG-2 & $4-\mathrm{NO}_{2}$ & $\mathrm{C}_{13} \mathrm{H}_{10} \mathrm{~N}_{2} \mathrm{O}_{3} \mathrm{~S}$ & $134-135$ & $70 \%$ & 0.72 & 10 \\
3. & KCG-3 & $3-\mathrm{OCH}_{3}$ & $\mathrm{C}_{14} \mathrm{H}_{13} \mathrm{NO}_{2} \mathrm{~S}$ & $<40$ & $50 \%$ & 0.62 & 12 \\
4. & KCG-4 & $3-\mathrm{NO}_{2}$ & $\mathrm{C}_{13} \mathrm{H}_{10} \mathrm{~N}_{2} \mathrm{O}_{3} \mathrm{~S}$ & $<40$ & $55 \%$ & 0.70 & 10 \\
5. & KCG-5 & $3-\mathrm{Cl}_{13}$ & $\mathrm{C}_{13} \mathrm{H}_{10} \mathrm{ClNOS}$ & $<40$ & $65 \%$ & 0.84 & 8 \\
6. & KCG-6 & $3-\mathrm{CH}_{3}$ & $\mathrm{C}_{14} \mathrm{H}_{13} \mathrm{NOS}$ & $<40$ & $55 \%$ & 0.91 & 10 \\
\hline \multicolumn{7}{c}{ Mobile phase: n-hexane: ethyl acetate: $2: 1$}
\end{tabular}




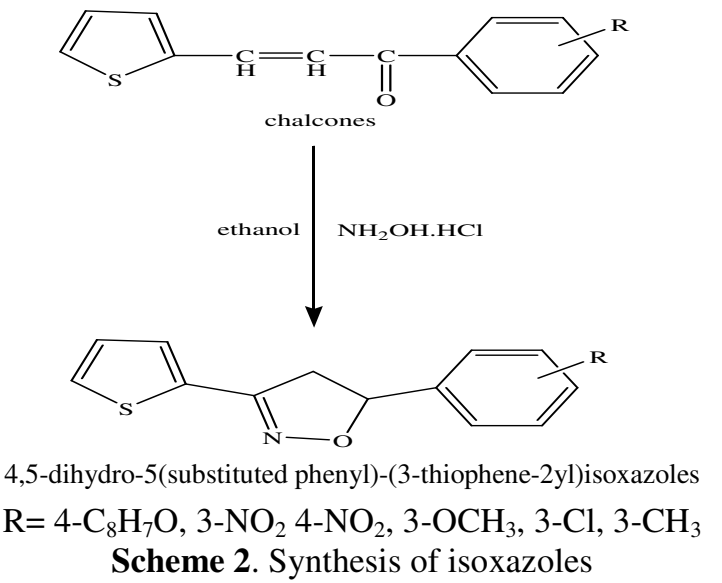

\section{Spectral data of synthesized compounds}

\section{4, 5-Dihydro-5-(4-benzyloxyphenyl)-3-(thiophene-2-yl)isoxazole (KCG-1)}

IR $\left(\mathrm{KBr} \mathrm{cm}^{-1}\right): 2909\left(-\mathrm{CH}_{2}-\right), 1509(=\mathrm{C}=\mathrm{N}-\mathrm{O}), 1225(\mathrm{C}-\mathrm{O})$ and712(C-S-C). ${ }^{1} \mathrm{H}$ NMR $\left(\mathrm{CDCl}_{3}\right)$ : $\delta 1.2009(\mathrm{~s}, 2 \mathrm{H}$, isoxazole ring), $\delta 4.985-5.090(\mathrm{t}, 2 \mathrm{H}$, benzyl) and $\delta 6.918-8.018(\mathrm{~m}, 12 \mathrm{H}, \mathrm{Ar}-\mathrm{H})$

\section{4, 5-Dihydro-5-(4-nitrophenyl)-3-(thiophene-2-yl)isoxazole (KCG-2)}

IR $\left(\mathrm{KBr} \mathrm{cm}^{-1}\right): 2937\left(-\mathrm{CH}_{2}-\right), \quad 1510(=\mathrm{C}=\mathrm{N}-\mathrm{O}), \quad 1344\left(\mathrm{NO}_{2}\right)$, and $714(\mathrm{C}-\mathrm{S}-\mathrm{C}) .{ }^{1} \mathrm{H}$ NMR $\left(\mathrm{CDCl}_{3}\right): \delta 1.214(\mathrm{~s}, 2 \mathrm{H}$, isoxazole ring) and $\delta 8.694-8.001(\mathrm{~m}, 7 \mathrm{H}, \mathrm{Ar}-\mathrm{H})$

4, 5-Dihydro-5-(3-methoxyphenyl)-3-(thiophene-2-yl)isoxazole (KCG-3)

IR $\left(\mathrm{KBr} \mathrm{cm}^{-1}\right): 2960\left(-\mathrm{CH}_{2}-\right), 1597(=\mathrm{C}=\mathrm{N}-\mathrm{O}), 1256(\mathrm{C}-\mathrm{O})$ and $775(\mathrm{C}-\mathrm{S}-\mathrm{C}) .{ }^{1} \mathrm{H} \mathrm{NMR}\left(\mathrm{CDCl}_{3}\right)$ : $\delta 1.225\left(\mathrm{~s}, 2 \mathrm{H}\right.$, isoxazole ring), 3.633-3.842(t, $\left.3 \mathrm{H}, \mathrm{OCH}_{3}\right)$ and $\delta$ 7.081-7.7.859 $(\mathrm{m}, 7 \mathrm{H}, \mathrm{Ar}-\mathrm{H})$

\section{4, 5-Dihydro-5-(3-nitrophenyl)-3-(thiophene-2-yl)isoxazole (KCG-4)}

IR $\left(\mathrm{KBr} \mathrm{cm}^{-1}\right): 2917\left(-\mathrm{CH}_{2}-\right), \quad 1605(=\mathrm{C}=\mathrm{N}-\mathrm{O}), \quad 1350\left(\mathrm{NO}_{2}\right)$, and772(C-S-C). ${ }^{1} \mathrm{H} \quad \mathrm{NMR}$ $\left(\mathrm{CDCl}_{3}\right): \delta 1.240(\mathrm{~s}, 2 \mathrm{H}$, isoxazole ring) and $\delta 8.095-8.655(\mathrm{~m}, 7 \mathrm{H}, \mathrm{Ar}-\mathrm{H})$

\section{4, 5-Dihydro-5-(3-chlorophenyl)-3-(thiophene-2-yl)isoxazole (KCG-5)}

IR $\left(\mathrm{KBr} \mathrm{cm}^{-1}\right): 2920\left(-\mathrm{CH}_{2}-\right), 1598(=\mathrm{C}=\mathrm{N}-\mathrm{O}), 1350(\mathrm{C}-\mathrm{Cl}$ aryl $)$ and $772(\mathrm{C}-\mathrm{S}-\mathrm{C}) .{ }^{1} \mathrm{H}$ NMR $\left(\mathrm{CDCl}_{3}\right): \delta 1.225(\mathrm{~s}, 2 \mathrm{H}$, isoxazole ring) and $\delta 7.011-7.8860(\mathrm{~m}, 7 \mathrm{H}, \mathrm{Ar}-\mathrm{H})$

\section{4, 5-Dihydro-5-(3-methylphenyl)-3-(thiophene-2-yl)isoxazole (KCG-6)}

IR $\left(\mathrm{KBr} \mathrm{cm}^{-1}\right): 3015\left(-\mathrm{CH}_{3}\right), 2917\left(-\mathrm{CH}_{2}-\right), 1581(=\mathrm{C}=\mathrm{N}-\mathrm{O})$ and $773(\mathrm{C}-\mathrm{S}-\mathrm{C}) .{ }^{1} \mathrm{H}$ NMR $\left(\mathrm{CDCl}_{3}\right)$ : $\delta 1.260\left(\mathrm{~s}, 2 \mathrm{H}\right.$, isoxazole ring), $\delta 4.120\left(\mathrm{~s}, 3 \mathrm{H}, \mathrm{CH}_{3}\right)$ and $\delta$ 7.015-7.868 $(\mathrm{m}, 7 \mathrm{H}, \mathrm{Ar}-\mathrm{H})$

\section{Antibacterial activity}

The antibacterial activity was assayed by agar plate disc diffusion method ${ }^{10}$ at the concentration of $50 \mu \mathrm{g}$ per disk. All the synthesized compounds were tested in vitro for their antibacterial activity against gram positive microorganisms such as Staphylococcus aureus, Bacillus subtilis and gram negative Escherichia coli, Pseudomonas aerugenosa strains. Each test compounds were dissolved in dimethyl sulphoxide (DMSO) to get required concentration. The discs (6 $\mathrm{mm}$ in diameter) were impregnated, air dried and placed on the agar medium, previously seeded with $0.2 \mathrm{~mL}$ of broth culture of each organism for $18 \mathrm{~h}$. 
The plates were incubated at $37^{\circ} \mathrm{C}$ for $24 \mathrm{~h}$ and the inhibition zones were measured in $\mathrm{mm}$. Discs impregnated with DMSO were used as a control and ciprofloxacin discs as antibacterial reference standard.

\section{Antifungal activity}

The antifungal activity ${ }^{11}$ was assayed by sabouraud dextrose agar media plate disc diffusion method at the concentration of $50 \mu \mathrm{g}$ per disk. All the synthesized compounds were tested in vitro for their antifungal activity against microorganisms such as Asperagellus niger and Candida albicans. Each test compound was dissolved in dimethyl sulphoxide (DMSO) to get required concentration. The discs (6 $\mathrm{mm}$ in diameter) were impregnated; air dried and placed on the sabouraud dextrose agar media, previously seeded with $0.2 \mathrm{~mL}$ of broth culture of each organism for $18 \mathrm{~h}$. The plates were incubated at $22{ }^{0} \mathrm{C}$ for $48 \mathrm{~h}$ and the inhibition zones were measured in mm. Discs impregnated with DMSO were used as a control and fluconazole discs as antifungal reference standard. The result of activity was described in the Table 3.

Table 3. Antifungal activity of the compounds

\begin{tabular}{ccccccc}
\hline Compound & \multicolumn{7}{c}{ Zone of inhibition in mm } \\
\cline { 2 - 7 } 50 g/disc & B.subtilis & S.aureus & E. coli & P.aeruginosa & A. niger & C. albicans \\
\hline KCG-1 & ++ & ++ & ++ & ++ & ++ & ++ \\
KCG-2 & - & - & - & - & - & - \\
KCG-3 & - & ++ & - & + & - & - \\
KCG-4 & ++ & ++ & ++ & ++ & ++ & + \\
KCG-5 & ++ & ++ & +++ & +++ & ++ & +++ \\
KCG-6 & ++ & ++ & ++ & ++ & ++ & +++ \\
Ciprofloxacin & +++ & +++ & +++ & +++ & & \\
Fluconazole & & & & & +++ & +++ \\
Solvent control & - & - & - & - & - & - \\
DMSO & & & & & & \\
\hline
\end{tabular}

Inactive (inhibition zone < $6 \mathrm{~mm}$ ); slightly active = '+' (inhibition zone 7-9 $\mathrm{mm})$; moderately. Active = '++' (inhibition zone 10-13 mm); highly active = '+++' (inhibition zone $>14 \mathrm{~mm}$ )

\section{Results and Discussion}

The IR spectra of the synthesized compounds (KCG 1-KCG 6) clearly showed the formation of isoxazoline ring by the appearance of band at $1509-1600 \mathrm{~cm}^{-1}(=\mathrm{C}=\mathrm{N}-\mathrm{O})$ stretching vibration and the attachment of Thiophene ring was confirmed by the appearance of band at $714-775 \mathrm{~cm}^{-1}(\mathrm{C}-\mathrm{S}-\mathrm{C})$ stretching vibration. The ${ }^{1} \mathrm{H}$ NMR data also confirmed the synthesis by showing $\delta$ values for various hydrogen. The ${ }^{1}$ HNMR spectra showed a singlet at about $\delta$ 1.225 for $2 \mathrm{H}$, isoxazole ring and multiplets for the aromatic hydrogen at about $\delta 7.0-7.8$. The attachment of various substituent groups in the synthesized compounds were also validated by their respective IR and ${ }^{1} \mathrm{H}$ NMR spectra. The compounds KCG-5 was found to be highly active against E. coli, $P$. aeruginosa and $C$. albicans. The enhanced activity of this compound may be attributed to the presence of chloride as a substituent on the aromatic ring collectively increasing the lipid solubility. The rest of the compounds KCG-1, KCG-4 and KCG-6 were found moderately to highly active. 


\section{Acknowledgement}

The authors are thankful to the Director, College of Pharmacy and the Managing Director, I.F.T.M. Moradabad (India) for providing research facilities. We also extend our thanks to the Director, National Collection of Industrial Microorganisms, National Chemical Laboratory, Pune (India) for providing the microbial strains.

\section{References}

1. Hans P and Walter P, US Patent, 1972, 3668215.

2. Hoffer M, US Patent, 1955, 2721200.

3. Sorithiya S D, Patel V B and Parikh A R, Indian J Chem., 1997, 36B, 822.

4. Doyle F P, Betchworth G and Charles J H, US Patent, 1961, 2996501.

5. Uno H, Kurokawa M, Masuda Y and Nishimura H, J Med Chem., 1979, 22, 180-183.

6. Haripara K, Patel S, Joshi A and Paresh H, Indian J Heterocycl Chem., 2004, 13, 221.

7. Wagner E, Becam L and Nowakowska E, Bioorg Med Chem., 2004, 12, 265-272.

8. Ngaini Z, Siti M Haris-Fadzillah, Hasnain Hussain and Kamarulzamon Kamoruddin, World J Chem., 2009, 4(1), 09-14.

9. Vogel A I, Textbook of Practical Organic Chemistry, $4^{\text {th }}$ Ed., Longman, 1981, 1371p.

10. Collin C H, Microbiological Methods, Butter Wrths, London, 1964, 92.

11. Gravestock M B and Ryley J F, Annual Reports in Medicinal Chem., 1984, 19, 127-136. 